\title{
The Roles of Neighborhood Cultural Spaces in the Development of Citizenship Culture
}

\author{
Malihe Izadi ${ }^{1} \&$ Jamal Mohammadi $^{1}$ \\ ${ }^{1}$ Ph.D. Candidate, University of Isfahan, Faculty of Geographic Planning Science, Isfahan, Iran \\ Correspondence: Jamal Mohammadi, Associated Professor of Geography and Urban Planning, University of \\ Isfahan, Faculty of Geographic Planning Science, Isfahan, Iran. Tel: 98-0313-7933-081. E-mail: \\ j.mohammadi@geo.ui.ac.ir
}

Received: December 10, 2015

Accepted: January 10, 2016

Online Published: January 13, 2016

doi:10.5539/mas.v10n3p89

URL: http://dx.doi.org/10.5539/mas.v10n3p89

\begin{abstract}
Cultural space constitutes the physical, cultural and perceptual attributes of a place that creates social phenomenon and place meaning. Thus, this paper discusses the roles of cultural spaces that Cultural spaces in neighborhoods as parts of thriving urban spaces are considered as the most potential urban spaces in the development of citizenship culture due to enjoying potentials and capacities. This study will look into how such cultural characteristics have influenced the revitalization of the local culture. Cultural spaces are considered as one set of the main instruments of cultural development in current societies and are burdened significant responsibility in developing human forces. Cultural spaces, as one set of the main important institutions for cultural services, have important functions in increasing the literacy and culture level of societies. Then establishment of such spaces and the mode of their distribution in the neighborhoods are, directly or indirectly, effective on the degree of individuals' reference and use of these spaces. The aim of the present study is to identify and analyze spatially the performance of cultural spaces of neighborhoods in the enhancement of citizenship culture. The results of the present study indicate that the development of cultural spaces results in decreasing the differences in urban culture and promoting appropriate citizenship behaviors and consequently, accessing citizenship culture development.
\end{abstract}

Keywords: cultural spaces, citizenship culture, urban identity, local community, neighborhood

\section{Introduction}

Cities around the world are building and branding urban cultural life as a way to develop local economies and revitalize urban centers. Over the past decade cities have focused substantial economic development and revitalization efforts and resources on enhancing their "creative" character (see Landry (2000)). Economic development scholar Richard Florida has promoted an enormously influential image of successful 21st century cities as places where social tolerance and natural and cultural amenities draw educated workers and new economy businesses (Florida, 2003, 2005, 2008).

Recently, there is a growing interest in cultural spaces. More venues are used as cultural spaces, through studies of their distinctive locality and cultural values.

A cultural space is recognized as a space or facility that can d directly produce and educate some cultural products in everyday life or where citizens can come and appreciate arts and culture: it is not just a place but a space in which the locality and cultural activities are organically connected to constantly for the production and enjoyment of culture. Therefore, its role should inevitably change along with the change of times (Choi et al., 2013).

Culture is something that individuals or groups "create", or alternatively something that such individuals or groups "receive". In other words, in order to trace the development of culture, it is necessary to consider the mutual relations between the three parties, the "creator", the "cultural property", and the "recipients", and they cannot be discussed separately from the conditions of the society that gave them birth (Okano et al., 2010). The forms of communication between the "creator" subject and the "receiver" subject are important.

Virtually, culture is the necessities of people life constantly practiced by community since past, in present and towards future (Orbasli, 2000). A culture is described as a group of people engage to the way of life inclusion 
thoughts and behaviour; values; beliefs; rules of conduct; political organization; and economic activity to convey from one generation to another via learning process (Young, 1994). In late 1980s, culturally led urban development began as a theoretical in urban planning field (Montgomery, 2003). In accordance to the UNESCO Intangible Heritage Glossary, cultural space delineated as "a physical or symbolic space for people meet to enact, share or exchange social practices or idea" (Zanten, 2002). Tuan (1980) elucidates culture is one of the attributes to devote the significance of a place. Therefore, culture is an important element to create an identity, a place as well as to regeneration an urban space through the physical development, economic vitality and social liveliness (Wansborough et al., 2000). This study will look into how such cultural characteristics have influenced the revitalization of the local culture. Cultural spaces in neighborhoods as parts of thriving urban spaces are considered as the most potential urban spaces in the development of citizenship culture due to enjoying potentials and capacities.

\subsection{Problem Statement}

Cultural spaces of neighborhoods as specific scientific, cultural, and physical spaces, and due to its particular features and functions in urban spaces can have diverse dimensions and functions in culture building and enhancing the performance of citizenship culture. Since on the one hand, urban neighborhood have lost their previous identity and a large part pf these problems have roots in the level of citizens' culture, and on the other hand, appropriate use of neighborhoods from cultural centers in enhancing in promoting citizenship culture and promoting constructive behaviors of citizens in urban spaces and providing grounds for access to sustainable development of urban culture. Therefore, main questions of the present study is what effects the existence of cultural spaces have in neighborhoods in reducing the gap between citizenship culture and urban appropriate state in accessing sustainable development? What effects do the construction of a cultural space have in a neighborhood on its own surroundings in terms of performance?

To find proper answers for these questions, some hypotheses are regulated as follows:

Cultural spaces of neighborhoods are effective on reducing the gap between citizenship culture and favorite urban states?

Cultural spaces in each neighborhood are effective on its own surrounding in terms of performance.

The aim of the present study is to develop citizenship culture for reducing physical, social, and cultural abnormalities and contribute to the realization of sustainable development of urban culture. In the present study, the role of cultural centers in developing urban culture was investigated.

\section{Literature Review}

\subsection{Culture and the Roles of Cultural Spaces}

The literature review with begin to discuss the meaning of the culture and cultural spaces. In general, culture is the most complex word in the English Language conveyed by William (1983). The definition of culture meant what people think, to perform and also composed of a process related to people way of life in the form of buildings, artefacts, art, customs, atmosphere and cultural (Richards, 2001). Montgomery (2003) describes culture is predominantly an imperative aspect to create urban public realm seeing like: spaces, streets, and squares in creating a city's identity. Concisely, stated that cultural space referent to an urban spatial associated with people activities, behavior (or perception), space prototypes and the surrounding characteristics (illustrated in Figure 1). Besides, they also highlighted cultural space has a strong implication tied to people's way of life. Cultural space is the collective of the phenomenon and a communal space to conduct a variety of activities. A cultural space also inter predated as allied to people behavioral and psychological spaces. 


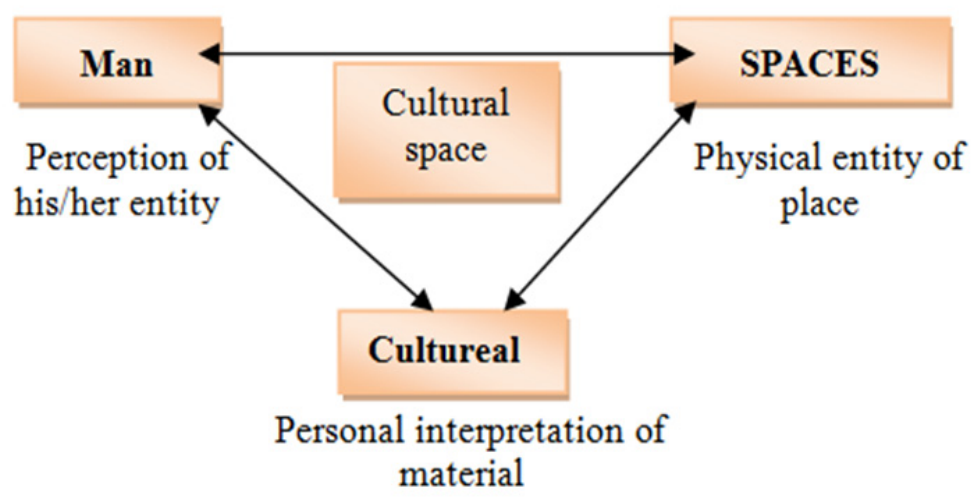

Figure 1. The correlation of man, space and culture indicates formation of cultural space

Source: Yoke Lai et al., 2013.

Their previous study inscribed that people utilised the urban space or open space considered as a cultural space. In general, the characters of cultural space were alike with the urban space constituted of the social factor, spatiality, physical aspect, neighborhood dimension and human perceptions (Ibid.). The similarities of the physical characteristics and cultural space meanings can be justified in the urban space lexicon. Hence, urban spaces comprehended as a cultural space whereby people gathered to gain the social space experiences. The typologies cultural spaces are social space, neighborhood space (known as found spaces or everyday spaces by Carr et al., 1992); human space; community space and existential space (recognised as lived space by Relph, 1976).

In Gehl (1971) standpoints, one or more than two people participate, movement, and interaction within a communal space recognized as social activities. These social activities occurred when necessary and optional activity occurred in the urban spaces or public spaces (e.g.: children play, people meeting, greeting, conservation, communal activity, and passive interaction) (Gehl, 1971; Carmona \& Tiesdell, 2007). Simultaneously, Ramezani, Zul Azri and Idid (2009) stated 'daily lifestyle' has created the powerful influences to the public space utilisation. Eventually, Dumericher and Kolb (2008) also emphasized the presence of the daily routines spaces conveyed to the enhancement of communal life in the society (Ramezani, Zul Azri, \& Idid, 2009).

Literally, cultural spaces in Malaysia analogue to the urban space prototypes for daily practices. The cultural spaces in Malaysia derived from trading and sociocultural activities conducted in Petaling shopping street; Kota Bharu marketplace; night market and hawker stall at Melaka streets, and compound of worship (Ahmad Bashri \& Shuhana, 2008). People integrated with the traditional street, marketplace and religious compound or a cultural space to perform their social activities like shopping, merchandise, social gathering, celebrates religious event, festival, funeral and wedding.

In sum, the roles of cultural spaces symbolized a place characteristic where people perceived the cultural phenomenon when associated to the urban space. In all, the significance of culture spaces, sociocultural and economic activities have formed the place meaning and sense of belonging to users.

\section{Methodology}

Cultural spaces are considered as one set of the main instruments of cultural development in current societies and are burdened significant responsibility in developing human forces. Cultural spaces, as one set of the main important institutions for cultural services, have important functions in increasing the literacy and culture level of societies. Then establishment of such spaces and the mode of their distribution in the neighborhoods are, directly or indirectly, effective on the degree of individuals' reference and use of these spaces. The study will adopt a qualitative research model. It will assess the views of the public on the role of media architecture and cultural spaces in maintaining the culture and identity of a particular metropolis. A survey using questioners will be conducted to collect data for the study. A short questioner with short structured questions. The present study is to develop citizenship culture for reducing physical, social, and cultural abnormalities and contribute to the realization of sustainable development of urban culture. In the present study, the role of cultural centers in developing urban culture was investigated. 


\section{Findings (Discussion and Analysis)}

Cultural development tends to geographically concentrate cultural resources into downtowns and cultural districts and away from neighborhoods. The cultural assets of neighborhoods are under-recognized and insufficiently supported. Neighborhood cultural assets and needs are poorly incorporated into the existing cultural policy infrastructure of most cities. Few cities have specified and institutionalized a role for city government in the cultural lives of urban neighborhoods.

The small-scale cultural ecosystems found in neighborhoods are fundamentally hybrid (Stern \& Seifert, 2008) and their needs are not well addressed by this system. This gap has several important consequences. Neighborhoods often are left out of the primary resource streams created through the local cultural policy infrastructure because they do not fit the types of programs that city cultural agencies were designed to target. For example, neighborhood cultural activities often are unincorporated and thus are ineligible for most grants (unless affiliated with a fiscal sponsor).

The result findings present the roles of cultural spaces as well the research conclusion to be discoursed accordingly in this discussion. Subsequently, the analysis part denotes two comparative case studies which based on that determinants attributes and the community perception on cultural spaces through questionnaire and interview survey.

From the perspective of urban planning, cultural spaces are among the most important spaces in cities which require particular attention. If we can regulate the structure and activities in urban planning in order to contribute to the development of deep and qualitative interactions and communications, naturally we will help enhancing the sense of belongingness to the space, identity, and supplying emotional needs of citizens in such a way that the development of cultural spaces, collective and urban entertainments and as such is considered important.

Simply, by urban cultural spaces it means those spaces in which interactions are provided for citizens. The significance of these spaces is that they are the most important workshops for the establishment of urban culture. It is in such spaces which the possibility of access to common understanding or at least understanding each other about urban issues are provided. It should be noted that a cultural space may be considered as inappropriate from the view of another group. In such a state, it is important that all individuals and groups, with each tendency and taste, can have their own favorite cultural spaces and the diversity and distribution of these spaces should be fair. Regarding the mentioned issues, it can be said that creating and retaining cultural spaces is one of the strategies of urban management which should be considered for then enhancement of urbanization culture.

Table 1. Intrinsic differences of classic cultural spaces planning and modern planning in urban neighborhoods

\begin{tabular}{|c|c|c|}
\hline & Classic cultural spaces planning in neighborhoods & Modern planning of cultural spaces \\
\hline Who & $\begin{array}{l}\text { External factors such as state organizations, } \\
\text { globalization processes, influential individuals, and } \\
\text { patterns of introducing by public media }\end{array}$ & cit \\
\hline What & $\begin{array}{l}\text { What the government and representatives identify. The } \\
\text { wants of powerful and influential groups }\end{array}$ & Wants of people and local communities \\
\hline How & top to bottom blueprint of centralized planning & $\begin{array}{l}\text { ed on local wants } \\
\text { y }\end{array}$ \\
\hline When & When problems occur and have been reached to severity & $\begin{array}{l}\text { Before the occurrence of problems and } \\
\text { in case of need }\end{array}$ \\
\hline Why & $\begin{array}{l}\text { Guaranteeing specific personal and group interests, } \\
\text { marginalizing citizens }\end{array}$ & $\begin{array}{l}\text { Empowering citizens, increasing the } \\
\text { spirit of participation, taking } \\
\text { responsibility, and enhancing the level } \\
\text { of components of social capitals }\end{array}$ \\
\hline
\end{tabular}

Source: the authors.

Cultural development of "citizenship cultural development" is a part of the concept of development, but this issue should be noted that achieving cultural development is relatively more difficult than the development of other sectors. Cultural development of "citizenship cultural development" is among the processes which can never be presented in a rudimentary and in short term period in the society, because this concept requires established and steady intellectual infrastructures. In fact, the cultural development of "citizenship cultural development" is realized in a society when the mentality of the individuals in that society has been changed and 
all have equal access to allowed cultural facilities in the society. Therefore, cultural spaces can create main functions in realizing cultural aims of development plans.

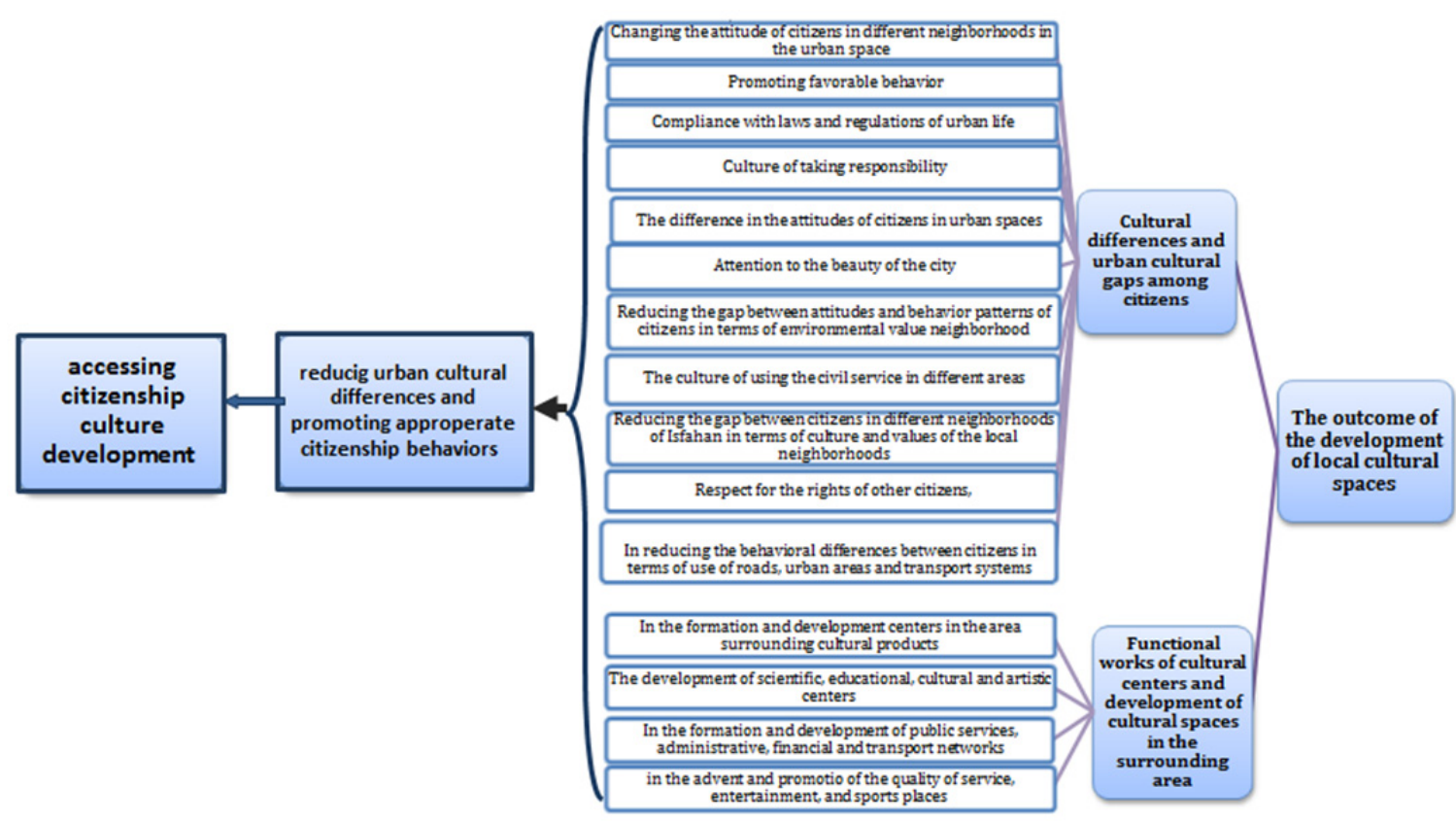

Figure 2. Research conceptual model, the outcome of cultural spaces development of neighborhoods in citizenship culture development

Source: designed by the authors.

In this section, regarding research hypotheses, to investigate the role of these centers in promoting urban culture, it is presented in the form of a suggested model indicating the cause-effect relationships among variables of cultural centers and urban cultural and it selected as the analytical model of the research.

According to the hypothetical model of the research, variables at the macro and micro levels were considered and main variables or dependent variables in this study are "cultural centers" and "promoting urban culture" which the relationship of these two with each other and also a set of continuous variables are considered. Figure 2 indicates the role of cultural centers in promoting urban culture and accessing urban sustainable development.

\section{Conclusion}

Regarding the results obtained from the present study, it can be learned that one of the axes of urban sustainable development is to create links and interactions among cultural centers and urban management which has not found its real status in Iran. Therefore, to introduce the status of cultural centers in promoting urban culture and achieving sustainable development of urban culture in the Metropolis of Isfahan, the following recommendations are presented according to the dimensions of sustainable development:

Optimal and favorable distribution of cultural centers in different neighborhoods in the City of Isfahan and paying attention to deprived neighborhoods in the positioning for spatially constructing and developing cultural centers and emphasizing more investment in the section of cultural spaces in different neighborhoods in the City of Isfahan for creating balance between humans, activities and urban spaces.

Cultural centers should have effective roles in culture building via providing educational activities in short-term and long-term periods for citizens and providing social services to institutions related to urban management.

Reinforcing public participation with the creation of NGOs.

Cultural centers are considered as the most important elements in developing the strategy of urban cultural planning in the process of cultural sustainable development of the city. Cultural planning for metropolises should be conducted via effective participation and cooperation of cultural centers and creation of active and efficient scientific networks via creating centers of connections between the city and cultural centers. 


\section{References}

Ahmad Basri, S., \& Suhanna, S. (2008). Lessons from Traditional Towns and Cities in Malaysia for Sustainable Future Places. In S. Ahmad Basri, \& M. M. Mouktar (Eds.), Urban Design Issues in the Developing World: The Case of Malaysia and Nigeria (pp. 1-21). Malaysia: University Technology Malaysia.

Carmona, M., \& Tiesdell, S. (2007). Urban Design Reader. UK: Architectural Press.

Choi, J. R., \& Dae Geun, L. (2013). Case Study of Cultural Space to Revitalize Local Community. International Journal of History and Culture, 1(1), 1-14. Retrieved from http://acascipub.com/Journals.php

Florida, R. (2003). The rise of the creative class. New York: Basic Books.

Florida, R. (2005). The flight of the creative class. New York: HarperCollins Books.

Florida, R. (2008). Who's your city? New York: Basic Books.

Gehl, J. (1971). Three Types of Outdoor Activities; Outdoor Activities and Quality of Outdoor Space. In M. Carmona, \& S. Tiesdell (Eds.), Urban Design Reader (pp. 152-155). UK: Architectural Press.

Landry, C. (2000). Creative cities: A toolkit for urban innovators. London: Earth scan Publications.

Montgomery, J. (2003). Cultural Quarters as Mechanisms for Urban Regeneration. Planning, Practice \& Research, 18(4), 293-306.

Okano, H., \& Samson (2010). Cultural urban branding and creative cities: A theoretical framework for promoting creativity in the public spaces. Cities, 27, 10-15.

Orbasli, A. (2000). Tourist in Historic Towns: Urban Conservation and Heritage Management. New York: E \& FN Spon.

Ramezani, S., Azri, Z., Abd, B., \& Idid, S. Z. A. (2008). Public Space and Conservation of an Historic Living City, 1-9.

Relph, E. (1976). Place and Pacelessness. London: Pion.

Richards, G. (2001). Attractions and European Tourism. UK: CABI Publishing.

Shuhana, S., \& Norsidah, U. (2008). Making places : The role of attachment in creating the sense of place for traditional streets in Malaysia. Habitat International, 32, 399-409. http://dx.doi.org/10.1016/j.habitatint.2008.01.004

Stern, M., \& Seifert, S. (2008). From creative economy to creative society. Progressive Planning, 170, 14-18.

Wansborough, M., \& Mageean, A. (2000). The Role of Urban Design in Cultural Regeneration. Journal of Urban Design, 5(2), 181-197.

Yoke, L., Lee, S., Ismail, K., \& Aya (2013). The Roles of Cultural Spaces in Malaysia's Historic Towns: The case of Kuala Dungun and Taiping. Procedia-Social and Behavioral Sciences, 85, $602-625$.

Young, R. M. (1994). Mental Space. Process press. Retrieved August 13, 2011, from http://human-nature.com

Zanten, W. V. (2002). GLOSSARY. Netherlands National Commission for UNESCO, 10-12.

\section{Copyrights}

Copyright for this article is retained by the author(s), with first publication rights granted to the journal.

This is an open-access article distributed under the terms and conditions of the Creative Commons Attribution license (http://creativecommons.org/licenses/by/3.0/). 